\title{
Late Quaternary variability of ocean circulation in the southeastern South Atlantic inferred from the terrigenous sediment record of a drift deposit in the southern Cape Basin (ODP Site 1089)
}

\author{
Gerhard Kuhn*, Bernhard Diekmann ${ }^{1}$ \\ Alfred Wegener Institute for Polar and Marine Research, P.O. Box 1201 61, 27515 Bremerhaven, Germany
}

Received 14 August 2000; accepted 5 December 2001

\begin{abstract}
During Leg 177 of the Ocean Drilling Program, an expanded sequence of Pliocene to Holocene calcareous muds was recovered at Site 1089 on a drift deposit in the southern Cape Basin (SE South Atlantic). The reconstruction of detrital sources and modes of sediment transport gives insight into the operational modes of regional current systems in response to climate variability over the last $590 \mathrm{kyr}$, as inferred from sedimentological and mineralogical parameters of the terrigenous sediment fraction. Terrigenous sediments mainly originate from African sources with minor contributions from distant southern sources (South America and Antarctica) and are supplied by circumpolar water masses, North Atlantic Deep Water (NADW), and surface currents of the Agulhas Current. Changes in clay mineralogy as tracers of deep and shallow ocean circulation, best displayed by variations in quartz/feldspar ratios and kaolinite/chlorite ratios of clay, reflect both the northward displacement of NADW injection into the Antarctic Circumpolar Current and a weakening of Agulhas Current leakage from the Indian Ocean around South Africa to the South Atlantic during glacial stages, sub-stages, and stadials. Modifications of these regional current patterns are consistent with perturbations in global conveyor circulation and climate variability on Milankovitch and subMilankovitch time scales. Elevated mass-accumulation rates of terrigenous matter generally document high particle fluxes and focusing effects by bottom-current action throughout the late Quaternary. Current sorting and coarsening of terrigenous mud, independently of its source signals, prevails during interglacial periods and is linked to a stronger flow of Antarctic Bottom Water and the invigoration of deep contour currents in response to long-term changes (100kyr cyclicity) in Antarctic ice-sheet dynamics, high-amplitude fluctuations in global sea level, and increased bottomwater formation. (c) 2002 Elsevier Science B.V. All rights reserved.
\end{abstract}

Keywords: South Atlantic; Pleistocene; palaeoclimate; Antarctic Circumpolar Current; Antarctic Bottom Water

\footnotetext{
1 Present address: Alfred Wegener Institute for Polar and Marine Research, Research Unit Potsdam, P.O. Box 6001 49, 14401 Potsdam, Germany.

* Corresponding author. Tel.: +49-471-4831-1204; Fax: +49-471-4831-1204.

E-mail address: gkuhn@awi-bremerhaven.de (G. Kuhn).
}

\section{Introduction}

During Leg 177 of the Ocean Drilling Program (ODP), an expanded sequence of Pliocene to Holocene calcareous muds was recovered at Site 1089 


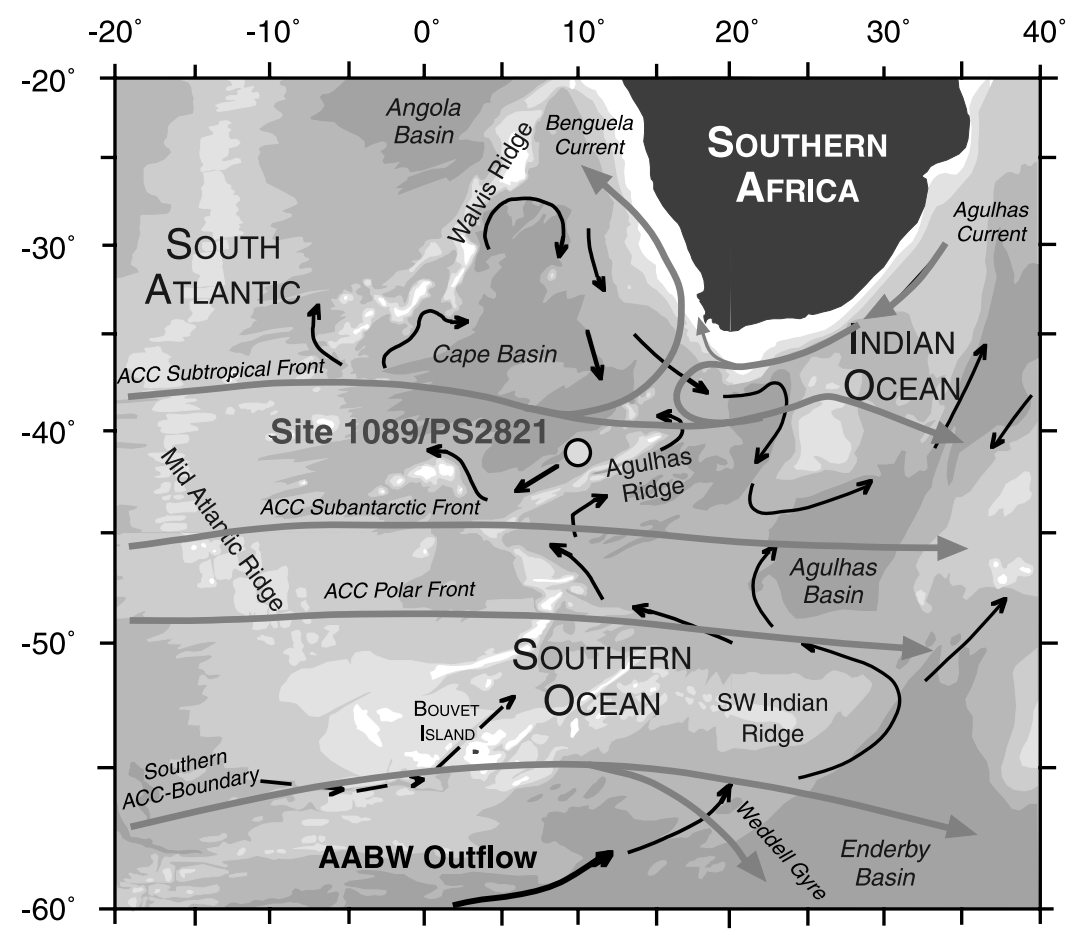

Fig. 1. Study area with position of ODP Site 1089 and sediment core PS2821-1 in the southeastern South Atlantic. Grey arrows depict the surface-ocean circulation pattern, comprising the frontal system of the Antarctic Circumpolar Current (ACC), the Benguela Current, and the Agulhas Current (Peterson and Stramma, 1991). Distal eddies and filaments of the Agulhas Current retroflection may reach as far as the core location (Lutjeharms, 1996). The flow pattern of bottom-contour currents, indicated by the dark arrows, appears independently of upper-level circulation (Tucholke and Embley, 1984). Sea floor below $2000 \mathrm{~m}$ is gradually shaded in steps of $1000 \mathrm{~m}$.

on a drift deposit in the southern Cape Basin (Gersonde et al., 1999) (Figs. 1-3). The site lies in the southeastern South Atlantic within the northern part of the Antarctic Circumpolar Current (ACC). The Quaternary drift sediments were deposited at high average sedimentation rates (15-20 $\mathrm{cm} \mathrm{kyr}^{-1}$ ), permitting high-resolution palaeoceanographic studies (Charles et al., 1996; Shipboard Scientific Party, 1999). The primary objectives of Site 1089 are to study the responses of the Southern Ocean to both glacial-interglacial climate oscillations caused by orbitally forced changes in insolation ('Milankovitch' cycles) and to climate variability on sub-orbital millennial time scales (referred to as 'Dansgaard-Oeschger' cycles in the northern hemisphere).

In this paper, we address temporal variations in terrigenous sediment supply. Fine-grained silici- clastics mostly originate from southern Africa, with minor contributions from equatorial Africa, South America, and from Antarctica, and they are delivered through ocean currents and winds to the Cape basin (Behairy et al., 1975; Bornhold and Summerhayes, 1977; Bremner and Willis, 1993; Diekmann et al., 1996; Petschick et al., 1996; Goldstein et al., 1999) (Fig. 2). Detrital input through ice-rafting is evident at Site 1089, but quantitatively plays a subordinate role, as indicated by the distribution of coarse lithic sand grains (Kanfoush et al., 2000). We will discuss the impact of climate variability on regional current patterns, inferred from depositional rates of terrigenous sediment components, from mineralogical tracers of water-mass configurations, and from silt grain sizes as indicators of relative bottom-current strengths. 


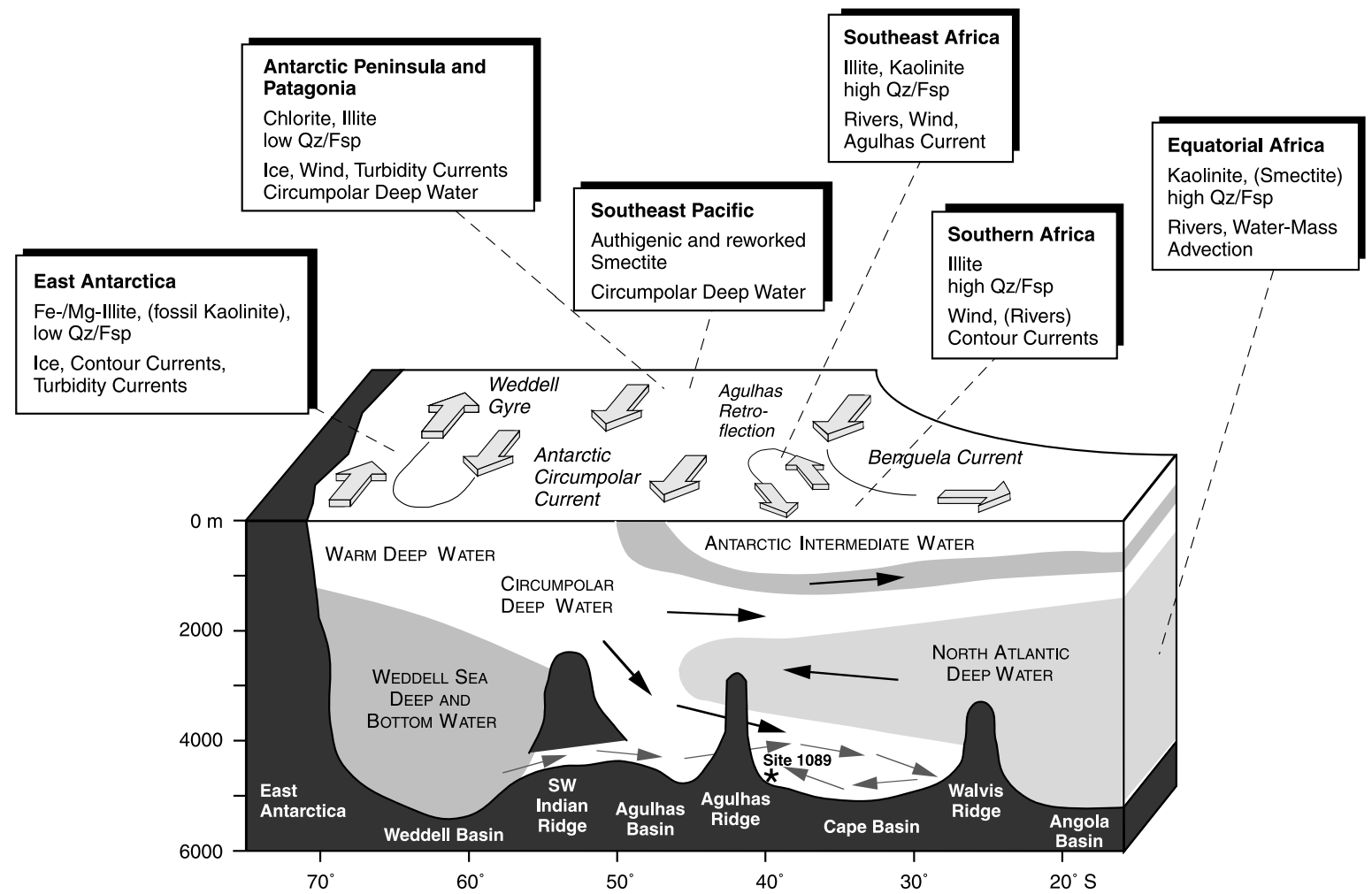

Fig. 2. Simplified model of ocean circulation and terrigenous sediment supply in the southeastern South Atlantic (modified from Diekmann et al., 1996).

\section{Regional oceanography}

Site 1089 lies at the southern margin of the Cape Basin and is situated within the northern part of the eastward flowing ACC (Figs. 1 and 2). It is bounded to the north by the Subtropical Gyre and the Benguela Current (Peterson and Stramma, 1991; Orsi et al., 1995). Moreover, the location is influenced from the northeast by the distal filaments of the Agulhas Current retroflection (Lutjeharms, 1996). ACC flow is driven by the southern westerly wind system and affects the whole water column. In the central part (Polar Front Zone) of the ACC, Antarctic surface water masses descend to form Antarctic Intermediate Water (AAIW) that spreads to the north between 500 and $1000 \mathrm{~m}$ water depth. Circumpolar Deep Water (CPDW) represents the main water mass of the ACC, encountered below the AAIW down to the sea floor (Reid, 1989). It represents an admix- ture of Weddell Sea, North Atlantic, Pacific, and Indian ocean waters with potential temperatures ranging from 0.1 to $2.0^{\circ} \mathrm{C}$. North of about $45^{\circ} \mathrm{S}$, the injection of relatively warm and saline North Atlantic Deep Water (NADW) at intermediate depths (2000-3500 m) splits CPDW into an upper and a lower layer.

High accumulation drift deposits along the rises of the southern Cape Basin are laterally continuous over at least $175 \mathrm{~km}$ and drape preexisting bedrock topography (Shipboard Scientific Party, 1999) (Fig. 3). The occurrence of these drift deposits, together with the configuration of density gradients within the bottom water masses, indicates the presence of a clockwise abyssal contour current in the Cape Basin (Bornhold and Summerhayes, 1977; Tucholke and Embley, 1984). Such a regional abyssal current pattern, which opposes the general ACC flow and which is directed by topography and coriolis forcing (Fig. 1), 


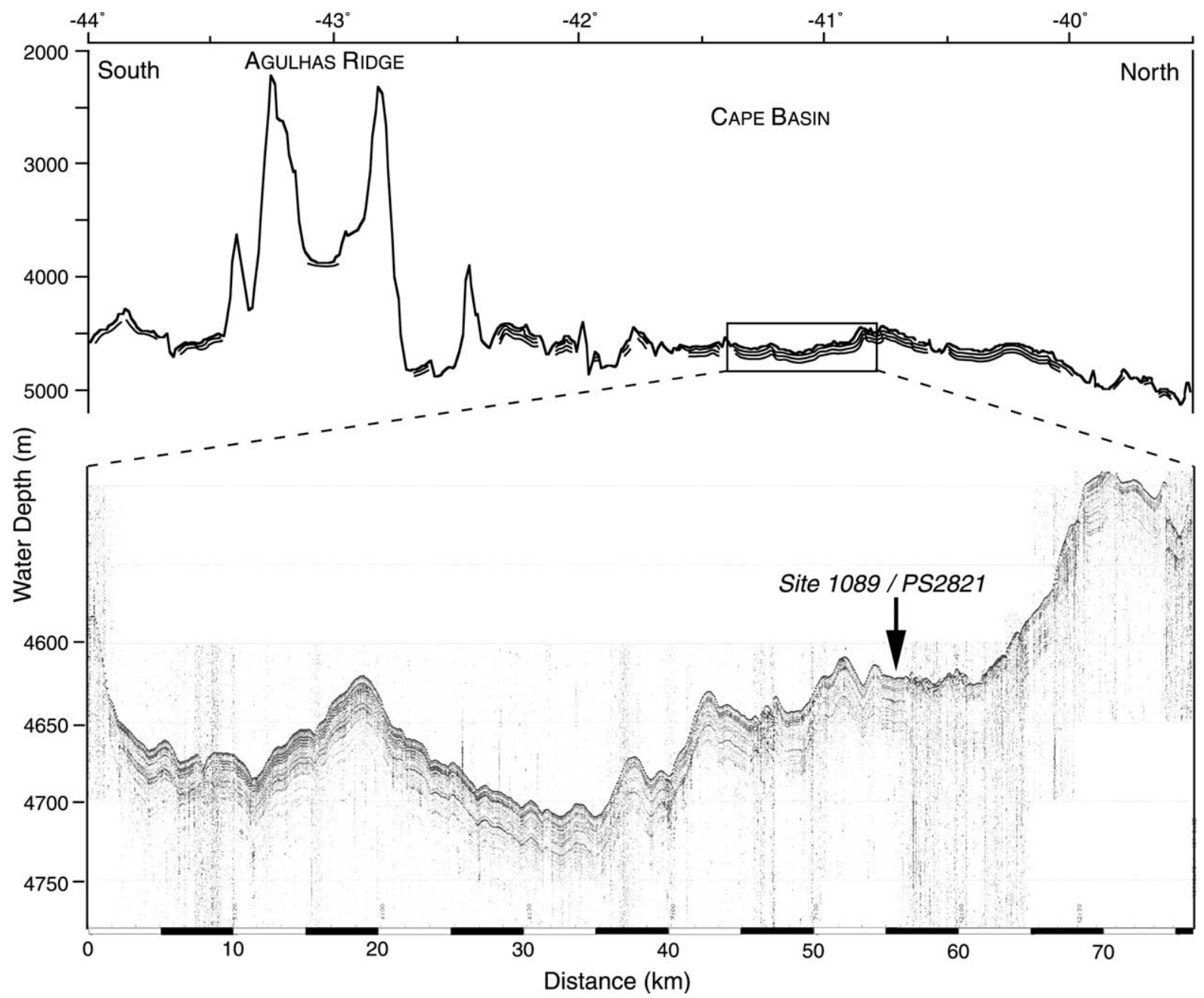

Fig. 3. (Upper graph) Bathymetric profile across the Agulhas Ridge and the sediment drifts of the southern Cape Basin. (Lower graph) 'Parasound' sub-bottom profile across Site 1089, which was obtained during a pre-site survey with research vessel Polarstern (Jokat and Oerter, 1998). It shows details of late Quaternary drift deposits that drape the rough topography of underlying sediments and bedrock.

was also inferred from an up-to-date ocean circulation model (Usbeck, 1999). The contour current very likely originates in the northward outflow of Weddell Sea water masses from the Enderby Basin through gaps in the SW Indian Ridge towards the Agulhas and Cape Basins (Tucholke and Embley, 1984) (Figs. 1 and 2). Continued flow and mixing with CPDW modifies the characteristics of the bottom water and gives the abyssal waters of the Cape Basin the properties of cold lower CPDW (Reid, 1989).

\section{Materials and methods}

\subsection{Selected sediment cores, stratigraphy, and sample base}

Site 1089 was drilled in a water depth of $4624 \mathrm{~m}$ north of the Agulhas Ridge $\left(40^{\circ} 56.18^{\prime} \mathrm{S}\right.$, $09^{\circ} 53.64^{\prime}$ E) (Figs. 1 and 3). Four drill holes penetrated a Pliocene to Holocene sequence of calcareous muds (Shipboard Scientific Party, 1999). This study was concentrated on the upper part 


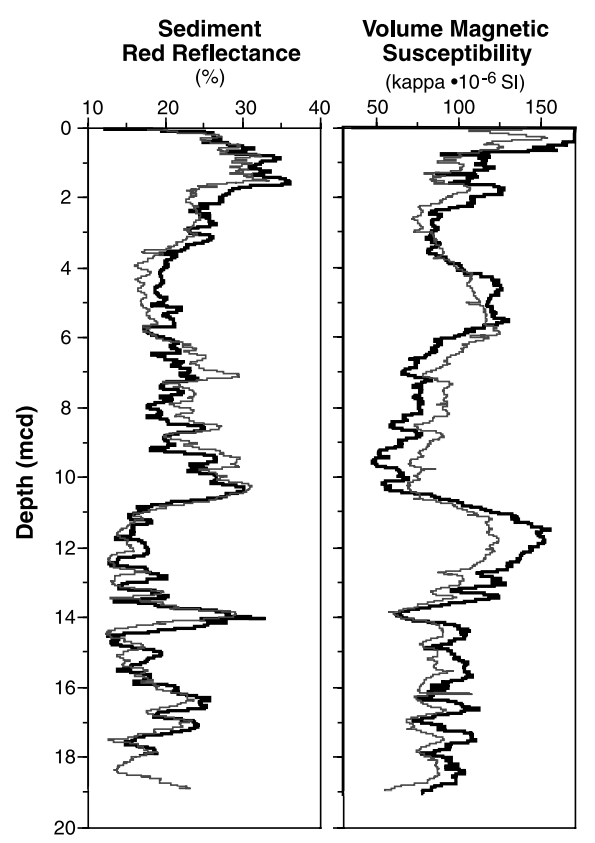

Fig. 4. Correlation of red-reflectance and volume magnetic susceptibility between the Site 1089 sediment record (thick lines) (Shipboard Scientific Party, 1999) and sediment core PS2821-1 (thin lines). Parameters are shown at Site 1089 mcd scale.

of the spliced composite section between 0 and 90 mod (metres composite depth), corresponding to the last $580 \mathrm{ka}$. For the upper part of the record, we refer to sediment core PS2821-1, recovered with a piston corer at the same position during a pre-site survey with research vessel Polarstern (Jokat and Oerter, 1998). The PS2821-1 and Site 1089 records were spliced at 14 mcd and the depth scale of PS2821-1 was converted to the Site 1089 mcd scale, by the correlation of downcore reflectance and magnetic-susceptibility data in both records (Fig. 4). For core PS2821-1, X-radiographs were made from $1-\mathrm{cm}$-thick slabs of the sediment, in order to recognise sedimentary structures (Fig. 5).

The applied age model and assignment of marine isotope stages (MIS) are based on the correlation of the benthic foraminiferal $\delta^{18} \mathrm{O}$ record of Site 1089 with the $\delta^{18} \mathrm{O}$ record of the SPECMAP standard stack (Hodell et al., 2001). Additional age markers for the MIS 1 to MIS 5 interval were obtained from radiolarian abundance strat- igraphy of Cycladophora davisiana (Cortese and Abelmann, 2002). Ages and stage boundaries refer to the time scales of Imbrie et al. (1984), for the 590-300-ka interval, and to Martinson et al. (1987), for the younger interval $(<300 \mathrm{ka})$.

Samples for bulk analyses were taken at $10-\mathrm{cm}$ intervals, representing time steps between 0.25 and $1.00 \mathrm{kyr}$. Mineralogical and granulometric analyses were conducted every $10 \mathrm{~cm}$ in the MIS 1 to MIS 6 interval, and at lower temporal resolution in the older strata: every $20 \mathrm{~cm}$ in the MIS 7 to MIS 11 interval, and every $30 \mathrm{~cm}$ in the MIS 12 to MIS 16 interval. The sample spacing is sufficient to resolve short-term events during the last glacial-interglacial cycle and to deduce Milankovitch cycles on longer time scales. We present original data at mcd scale, whereas illustrated time series were resampled by linear integration at equal time increments of $2 \mathrm{kyr}$ and $1 \mathrm{kyr}$ with the AnalySeries software (Paillard et al., 1996). The 2-kyr data were also used for powerand cross-spectral time-series analyses, conducted with the ARAND software (Ohio State University). Techniques are described in detail by Imbrie et al. (1989). Sample specifications and data lists can be extracted from the PANGAEA data information system (www.pangaea.de).

\subsection{Bulk-sediment parameters and mass-accumulation rates}

Bulk composition was determined on freezedried and ground sub-samples. Carbonate, organic carbon and nitrogen were measured on Leco Carbon Determinators (CS-125, CS-400 and CNS-2000). Biogenic silica (opal) was measured by an automated leaching method (Müller and Schneider, 1993). The remaining proportion of non-biogenic siliciclastic constituents is regarded as the terrigenous sediment fraction. Ratios of $\mathrm{C}_{\text {org }} / \mathrm{N}$ are discussed as an indicator of terrigenous organic matter. Values $>15$ point to abundant terrigenous organic matter, whereas values $<15$ indicate the dominance of marine organic matter (Knies et al., 1999).

Mass-accumulation rates (in $\mathrm{g} \mathrm{cm}^{-2} \mathrm{kyr}^{-1}$ ) of terrigenous matter $\left(\mathrm{MAR}_{\mathrm{Terr}}\right)$ were calculated by multiplying linear sedimentation rates with values 

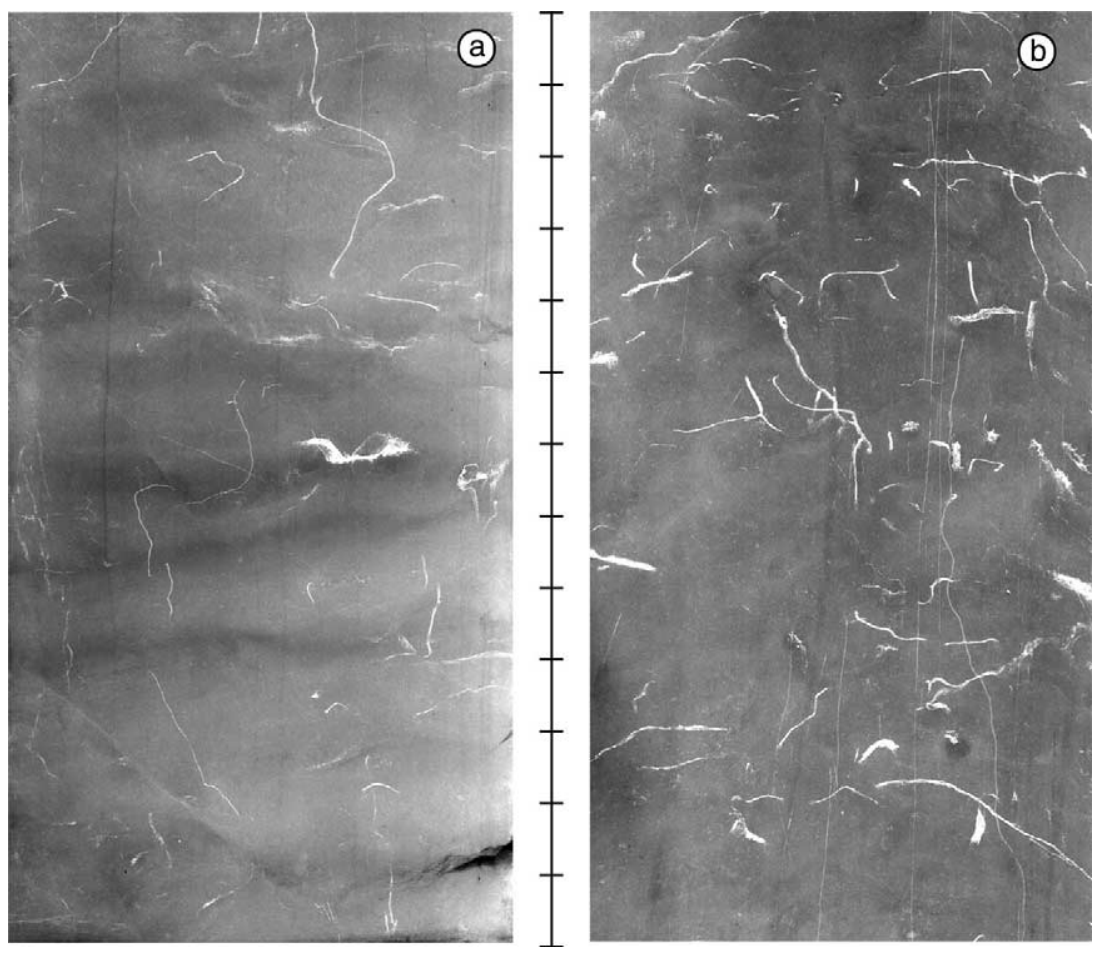

Fig. 5. X-radiographs from sediment core PS2821-1, showing representative sedimentary structures of interglacial and glacial intervals: (a) interglacial sediments of MIS 5 between 1440 and $1453 \mathrm{~cm}$ core depth, (b) glacial sediments of MIS 2 between 364 and $377 \mathrm{~cm}$ core depth (scale bar with 1-cm increments). Faint stratification in the MIS 5 interval (a), overprinted by bioturbation, supports the granulometric finding of relatively strong bottom-current activity during interglacial periods. In contrast, the more homogeneous structure of the MIS 2 interval with abundant authigenic pyrite streaks points to weaker current action and a reduced ventilation of likely both bottom and pore waters during glacial periods.

of dry-bulk density and the proportions of the terrigenous sediment fraction. Dry-bulk densities were inferred from dry-sediment densities, measured with a 'micromeritics AccuPyc 1330' pycnometer, and continuously shipboard measured wet-bulk densities by $\gamma$-ray attenuation with a multisensor track (Shipboard Scientific Party, 1999). The inferred dry-bulk densities for the sample set used for this study agree well with shipboard measurements of dry-bulk density in the course of physical-property investigations (Shipboard Scientific Party, 1999). Moreover, we calculated mass-accumulation rates of terrigenous silt and clay $\left(\mathrm{MAR}_{\text {Silt }}, \mathrm{MAR}_{\text {Clay }}\right.$ ), according to their weight proportions in the samples. Mass-accumulation rates of kaolinite and chlorite $\left(\mathrm{MAR}_{\mathrm{Kao}}\right.$, $\left.\mathrm{MAR}_{\mathrm{Chl}}\right)$ were estimated from $\mathrm{MAR}_{\text {Clay }}$ values and the relative proportions of the individual clay minerals, under the assumption that beside quartz and feldspar, clay minerals generally make up $80 \%$ of the clay fraction in sediment cores of the southeastern South Atlantic (see Diekmann et al., 1999).

\subsection{Clay and silt mineralogy}

Mineralogical analyses were carried out by Xray diffraction measurements on random silt mounts and on glycolated preferentially oriented clay mounts. Sample preparation and semi-quantitative evaluation of X-ray diffractograms followed techniques explained in detail elsewhere (Ehrmann et al., 1992; Petschick et al., 1996). Mineral proportions are calculated from weighted 


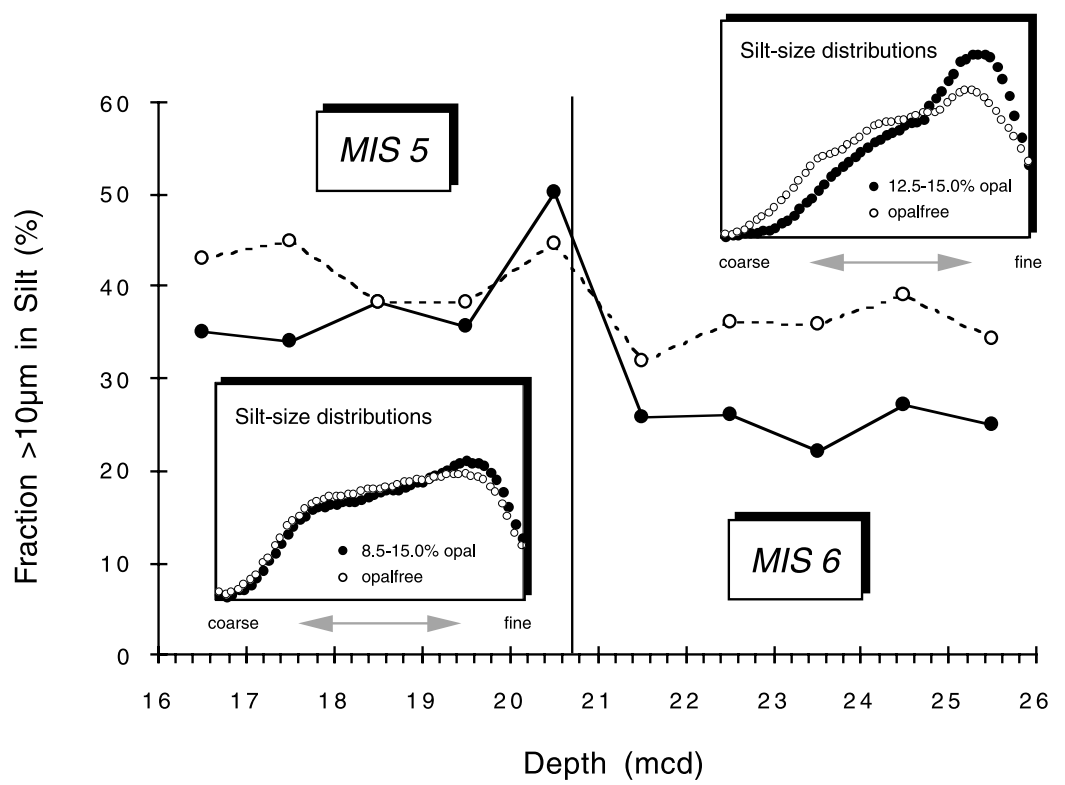

Fig. 6. Comparison of grain-size distributions (1/10-Phi steps) in carbonate-free silt samples and leached (opal-free) carbonatefree samples from Site 1089 across the MIS 5/MIS 6 boundary.

peak areas recorded in the X-ray diffractograms. Quartz/feldspar ratios (Qz/Fsp) in both the silt and the clay samples refer to the quotient of the $4.26-\AA$ peak area $* 5$ of quartz divided by the $3.19-3.24-\AA$ double peak area of plagioclase and $\mathrm{K}$-feldspar. The relative abundance of the claymineral groups in the clay fraction is summed to $100 \%$ using standard weighting factors as follows (Biscaye, 1965): the $17-\AA$ peak area for smectite, the 10 - $\AA$ peak area $* 4$ for illite, and the 7 - $\AA$ peak area for kaolinite and chlorite subdivided in proportion to the relative areas of their $3.57-\AA$ and

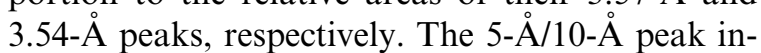
tensity ratio is a measure of illite chemistry. Values $>0.40$ indicate the presence of Al-rich illites (muscovite, sericite), values $<0.15$ indicate $\mathrm{Fe}-$ Mg-rich illites ( $<$ biotitic illite). The mineralogical data are used to trace the sources and transport paths of detrital matter.

\subsection{Grain-size analyses}

For the granulometric characterisation of terrigenous silt and clay, sub-samples were washed through a $63-\mu \mathrm{m}$ mesh for grain-size separation of sand and gravel from silt and clay. The fine fraction was treated with $3 \%$ hydrogen peroxide solution and $10 \%$ acetic acid for disaggregation and the removal of organic carbon and carbonate. Silt and clay then was separated at $2 \mu \mathrm{m}$ in settling tubes. The silt fraction was dispersed in sodium polyphosphate solution and measured with a 'Micromeritics SediGraph 5000E' to determine the grain-size distribution of silt in $1 / 10$-Phi steps. We used silt samples instead of mud samples to get a higher resolution of coarse silt and to avoid flocculation effects caused by the high abundance of smectite in the samples (Stein, 1985).

Since we only analysed carbonate-free samples, the measured grain-size distributions might be biased by the individual grain-size distributions of opaline particles. However, opal concentrations are generally below $15 \%$ in the carbonate-free samples, ruling out a significant impact of opal on terrigenous grain-size patterns. Moreover, Terr/Opal ratios vary independently of silt grainsize parameters (Fig. 7). To test these assumptions, we removed opal in a selected set of silt samples between 16 and $26 \mathrm{mcd}$, where marked gradients in silt size and silt/clay ratios appear 


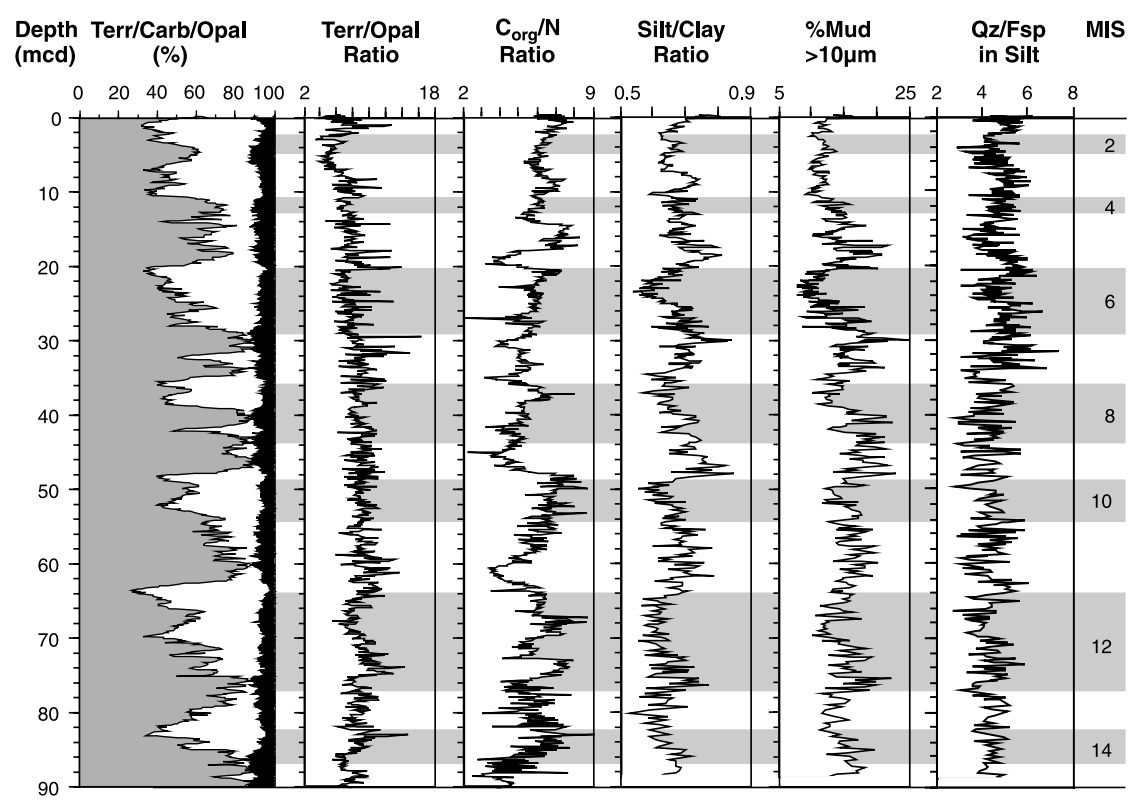

Fig. 7. Bulk-sediment parameters at Site 1089 versus depth. Silt/clay ratios and percentage mud $>10 \mu \mathrm{m}$ were measured on carbonate-free samples. Terr $=$ terrigenous sediment fraction, $\mathrm{Carb}=$ carbonate, $\mathrm{Qz}=$ quartz, Fsp $=$ feldspar.

through the upper MIS 6 to lower MIS 5 interval, with higher proportions of fine silt and clay in the MIS 6 interval (Fig. 6). According to standard procedures, samples were leached in $2 \mathrm{M} \mathrm{Na}_{2} \mathrm{CO}_{3}$ solution at $85^{\circ} \mathrm{C}$ for $5 \mathrm{~h}$ (McCave et al., 1995).

The resulting grain-size distributions of the residues compared to those of the opal-bearing samples only show slight differences and mainly concern lower concentrations of fine silt in the residues (Fig. 6). Because the opal concentrations vary in a similar range in the MIS 5 to MIS 6 intervals, the decrease in fine silt suggests that the leaching method - beside opal - also attacks the clay minerals in the fine silt fraction. This effect becomes particularly obvious in the clay-rich MIS 6 interval. Thus, the impact of opal on the modification of terrigenous silt grain-size distributions is negligible compared to the leaching effect of clay minerals. Therefore, we only rely on grainsize distributions of unleached carbonate-free samples, which are discussed in terms of silt/clay ratios and proportions of non-cohesive sortable silt (particles $>10 \mu \mathrm{m}$ ) in the $<63-\mu \mathrm{m}$ fraction. The latter parameter has been established as a qualitative proxy of relative changes in bottomcurrent strengths (McCave et al., 1995).

\section{Results and discussion}

\subsection{Relative and absolute terrigenous sediment input}

The relative proportions of the terrigenous sediment fraction show high-amplitude variations between 30 and $90 \%$, due to the dilution effects caused by biogenic components. The variations appear independently of glacial-interglacial cycles, because of the unusual preservation pattern of biogenic carbonate at Site 1089. Carbonate reveals low concentrations in both interglacial maxima (e.g. MIS 5.5) and glacial maxima (e.g. MIS 2), whereas high concentrations are related to moderate interglacials (e.g. MIS 3) (Hodell et al., 2001). Accordingly, percentages of terrigenous matter exhibit a reverse downcore pattern (Fig. 7). The terrigenous/opal ratio (biogenic opal forms a minor biogenic component $\leq 12 \%$ but is less susceptible to dissolution) shows no significant variation downcore, suggesting no systematic variations in relative terrigenous input. Whereas the composition of the terrigenous sediment fraction (silt/clay ratio, percentage of sortable silt, clay mineral composition) clearly shows system- 


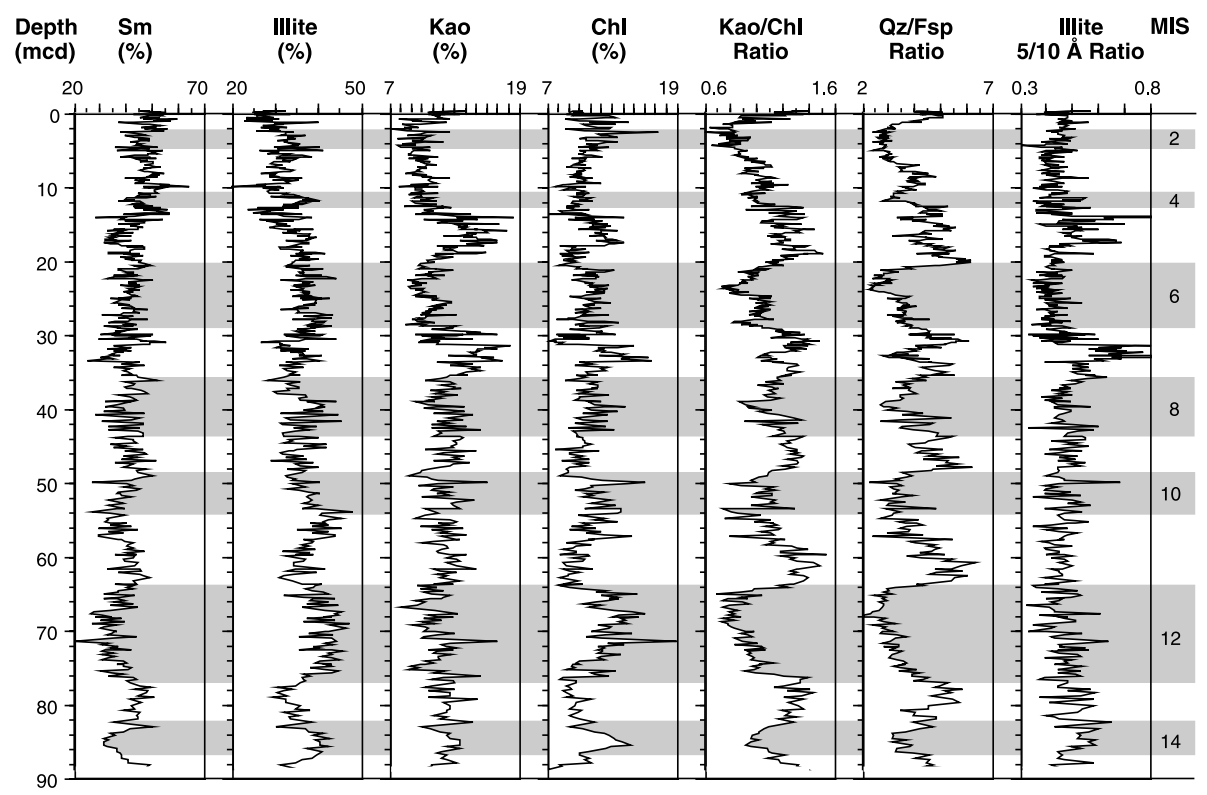

Fig. 8. Mineralogical parameters of terrigenous clay at Site 1089 versus depth. $\mathrm{Sm}=$ smectite, Kao= kaolinite, Chl=chlorite, $\mathrm{Qz}=$ quartz, Fsp = feldspar.

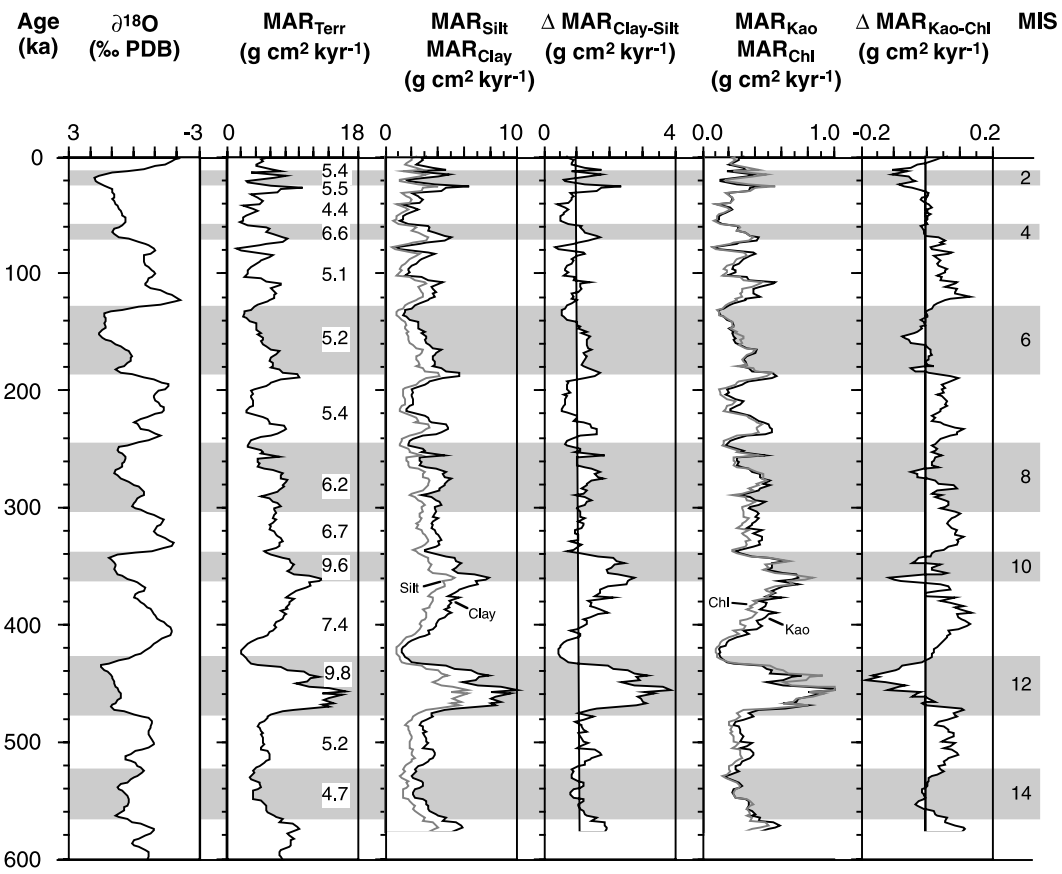

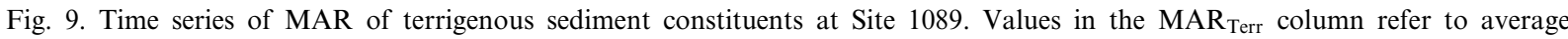
MAR $_{\text {Terr }}$ in the respective MIS intervals. Left column shows the benthic foraminiferal $\delta^{18}$ O SPECMAP stack, as a proxy of global ice volume and sea level (Imbrie et al., 1984). All values were resampled at $2-\mathrm{kyr}$ time increments. Terr $=$ terrigenous sediment fraction, $\mathrm{Kao}=$ kaolinite, $\mathrm{Chl}=$ chlorite . 


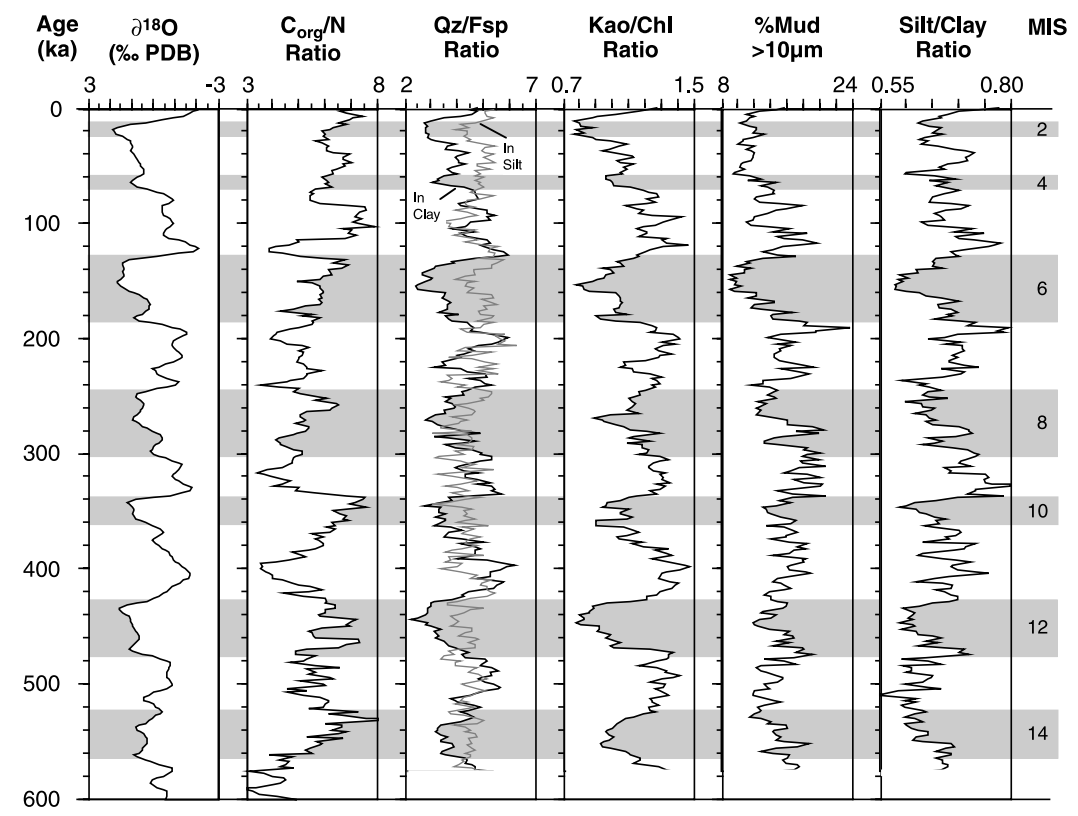

Fig. 10. Time series of terrigenous sediment parameters at Site 1089. Left column shows the benthic foraminiferal $\delta^{18} \mathrm{O}$ SPECMAP stack, as a proxy of global ice volume and sea level (Imbrie et al., 1984). All values were resampled at 2-kyr time increments. $\mathrm{Kao}=$ kaolinite, $\mathrm{Chl}=$ chlorite .

atic variations downcore (Figs. 7 and 8). Low $\mathrm{C}_{\mathrm{org}} / \mathrm{N}$ ratios $(<15)$ indicate a dominance of marine organic matter (Knies et al., 1999). Mostly increased values in glacial intervals may document a relatively enhanced input of terrigenous organic matter. However, that also could be explained by lower marine biological export production together with a constant terrigenous organic matter flux.

The absolute input of terrigenous matter, as

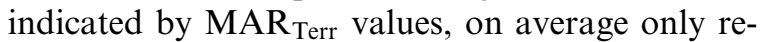
veals small-scale fluctuations between 4.5 and $6.7 \mathrm{~g}$ $\mathrm{cm}^{-2} \mathrm{kyr}^{-1}$ (Fig. 9). Peak values appear in MIS 12 and MIS 10 (9.78 and $9.62 \mathrm{~g} \mathrm{~cm}^{-2} \mathrm{kyr}^{-1}$ ) as well as in MIS $11\left(7.4 \mathrm{~g} \mathrm{~cm}^{-2} \mathrm{kyr}^{-1}\right)$. Not averaged values exhibit considerable variability in MAR $_{\text {Terr }}$. High values up to $17 \mathrm{~g} \mathrm{~cm}^{-2} \mathrm{kyr}^{-1}$ and $12 \mathrm{~g} \mathrm{~cm}^{-2} \mathrm{kyr}^{-1}$ are reached in MIS 12 and MIS 10. During transition from MIS 12 to MIS 11 the values drop back to $2 \mathrm{~g} \mathrm{~cm}^{-2} \mathrm{kyr}^{-1}$. Compared to other pelagic core locations in the southeastern Atlantic sector of the ACC, where late Quaternary $\mathrm{MAR}_{\mathrm{Terr}}$ range between 0.5 and $0.25 \mathrm{~g} \mathrm{~cm}^{-2} \mathrm{kyr}^{-1}$ (Froelich et al., 1991; Diek- mann et al., 1999), the MAR $\mathrm{Merr}_{\text {values at the drift }}$ Site 1089 are high and apparently point to elevated fluxes and focusing effects of terrigenous matter induced by bottom-current action. In the entire Atlantic sector of the ACC, MAR ${ }_{\text {Terr }}$ was usually higher during glacial periods (Diekmann et al., 1999, 2000). At Site 1089, such clear glacial-interglacial contrasts are only evident for the MIS 12 to MIS 10 interval. Higher accumulation rates during this time period correspond to lower silt/clay ratios and per cent sortable silt (Fig. 10). This documents a focusing effect of finer sediment fractions during weaker bottom-current activities. As shown later, these bottom currents are related to the $100-\mathrm{kyr}$ periodicity of climate response (global ice volume), whose amplitudes were largest during MIS 12 to MIS 10 and which dominates low precession and obliquity amplitudes during that time period (Berger, 1999).

\subsection{Sources of terrigenous mud and modes of detrital input}

From the generally high Qz/Fsp ratios in silt 
$(>3.0)$ and clay $(>2.5)$ and from the clay-mineral assemblage (Figs. 7 and 8), African regions can be inferred as principal source areas of terrigenous detritus in the southern Cape Basin, with minor contributions from more distant sources (Fig. 2). The average clay-mineral assemblage, including standard deviations, consists of: smectite $(42 \pm 6 \%)$, illite $(35 \pm 5 \%)$, kaolinite $(11 \pm 2 \%)$, and chlorite $(11 \pm 2 \%)$. Intermediately high $5 / 10$ - $\AA$-illite peak ratios $(0.46 \pm 0.07)$ indicate admixtures of Al-rich illites with $\mathrm{Mg} / \mathrm{Fe}$-bearing illites throughout the section.

In contrast to the other clay-mineral species, smectite from continental sources and offshore volcanic islands (South Sandwich Islands, Bouvet Island) alone cannot explain the generally high smectite concentrations found in the marine sediments of Site 1089 and large parts of the South Atlantic, as well (Petschick et al., 1996). This conclusion is based on the low concentrations of smectite in aeolian dusts and nearshore surface waters along the African coast (Chester et al., 1972; Behairy et al., 1975) and also in clay samples from sediment traps deployed in the ACC region at different depth levels (Petschick, unpublished data). Most smectite probably is introduced through Drake Passage via the ACC, originating from the erosion of hydrothermal and authigenic smectite-bearing sediments, widespread in the southeastern Pacific Ocean (Gorbunova, 1976; Honnorez, 1981; Cole and Shaw, 1983). Likewise, the scouring of exposed pre-Pleistocene sediments on the Falkland Plateau contributes to smectite fluxes in the ACC (Robert and Maillot, 1983; Walter et al., 2000).

High abundances of Al- and Fe/Mg-bearing illite at Site 1089 point to soils and dusts from southern Africa that are highly illite-bearing, beside low amounts of the other clay minerals (Van der Merve, 1966; Chester et al., 1972). Particulates from there are supplied to the ocean through the southeastern trade winds and to a lesser extent by fluvial input and during flash flood events (Bremner and Willis, 1993; Gingele, 1996; Petschick et al., 1996). Nearshore detritus may be reworked by along-shore currents or is transferred to the deep sea via turbidity currents, where parts of the suspensions may be entrained into the con- tour currents (Bornhold and Summerhayes, 1977; Tucholke and Embley, 1984).

The Agulhas Current represents an important carrier of kaolinite from southeast African aeolian and fluvial sources, and accounts for kaoliniteillite-dominated clay-mineral assemblages in marine sediments of the western Indian Ocean (Kolla et al., 1976). In the southern Cape Basin, detrital contributions via the Agulhas Current are actually well constrained by strontium isotope tracers of sediment provenance (Goldstein et al., 1999). Another distant source of kaolinite is the suspended sediment load of the low-latitude rivers of western Africa (Eisma et al., 1978; Pastouret et al., 1978). Parts of the fluvial suspensions reaching the open ocean are transferred farther to the south through particle advection within NADW (Petschick et al., 1996; Diekmann et al., 1996). In contrast, chlorite is predominantly delivered via CPDW (Petschick et al., 1996). It mostly derives from low-grade metamorphic and basic to intermediate magmatic rocks of the Antarctic Peninsula and Patagonia, mainly delivered to the ACC through glaciogenic input, particularly during glacial periods (Diekmann et al., 2000).

The mineralogical composition of silt and clay exhibits low variability through the section (Fig. 7), pointing to little variability in sediment sources and regional background sedimentation. However, $\mathrm{Kao} / \mathrm{Chl}$ ratios and Qz/Fsp ratios in the clay fraction display marked glacial-interglacial fluctuations, each with lower values in glacial intervals (Figs. 8 and 10). This can be attributed to variations in the relative input of the minor and exotic clay components that originate from distant sources in contrasting climatic settings and reach the site within different water masses (Diekmann et al., 1996; Petschick et al., 1996). The common fluctuations of both ratios are not surprising, since kaolinite is a weathering product of feldspar in the warm-humid regions with strong chemical weathering, while feldspar and chlorite persist in high latitudes and arid regions with prevailing mechanical weathering (Chamley, 1989). Detrital materials from warm-humid regions thus exhibit high Qz/Fsp and Kao/Chl ratios and vice versa for those materials from deserts and nival regions. Moreover, unweathered chlor- 
ite-bearing source rocks from the latter sources do not contain primary kaolinite and generally have low quartz concentrations.

\subsection{Regional conveyor circulation in response to climate variability}

Temporal fluctuations in Kao/Chl and Qz/Fsp ratios of the clay fraction as water-mass tracers monitor temporal changes in regional ocean circulation with high values of both ratios during interglacial periods (Figs. 10 and 11), which indicate the southward propagation of kaolinite- and quartz-rich suspensions, entrained in the filaments of the Agulhas Current retroflection and within NADW. During glacial periods, represented by low $\mathrm{Kao} / \mathrm{Chl}$ and $\mathrm{Qz} / \mathrm{Fsp}$ ratios, the ACC region is mainly bathed by the chlorite-rich and quartzpoor suspensions of the CPDW. The climatic relevance of temporal variability in water-mass advection is confirmed by cross-spectral analyses between clay-mineral ratios and the foraminiferal $\delta^{18} \mathrm{O}$ record of the reversed SPECMAP stack, as a proxy of global ice volume on a Milankovitch time scale (Imbrie et al., 1984) (Fig. 12). Thus, the periodogram of the Qz/Fsp ratio reveals significant spectral power in the $100-\mathrm{kyr}^{-1}, 41-\mathrm{kyr}^{-1}$, and $23-\mathrm{kyr}^{-1}$ frequency bands of orbital eccentricity, obliquity, and precession, highly coherent and almost in phase with changes in global ice volume. Variations in regional ocean circulation are also evident on a millennial time scale, particularly for MIS 3. Thus, maxima in Qz/Fsp ratios nearly match four warm interstadials, documented in the Vostok ice core (Fig. 11). These four interstadials even correspond to the pronounced and likely simultaneous DansgaardOeschger interstadials $8,12,14$, and $16 / 17$, recorded in the Greenland GISP2 ice core (Bender et al., 1999).

Variations in the regional current pattern are of global significance. The southeastern Atlantic plays an important role in global conveyor circulation, as it represents a junction of globally important water masses, including NADW, CPDW and warm surface waters of the Agulhas Current (Keir, 1988), which can be traced by clay mineralogical parameters. These water masses form

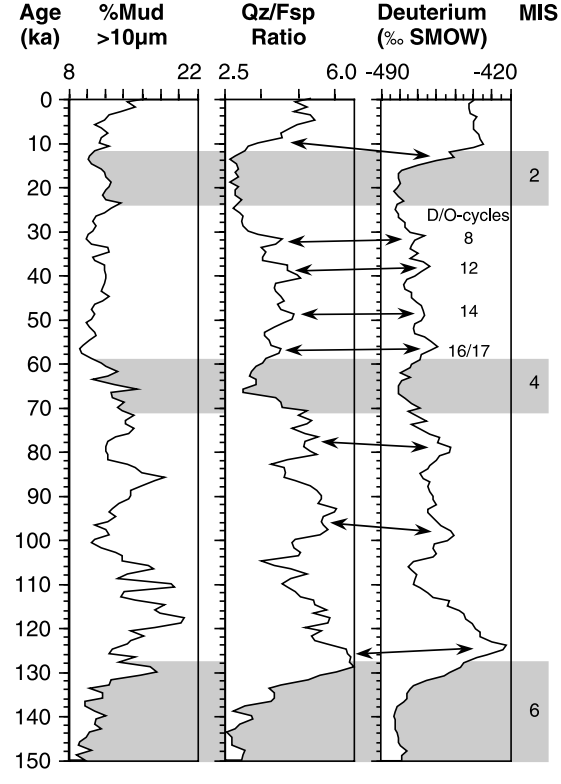

Fig. 11. Time series of percentage sortable silt and quartz/ feldspar ratios (Qz/Fsp) for the last $150 \mathrm{ka}$ resampled at 1-kyr time increments versus SPECMAP age scale. Right column shows the deuterium record of the Vostok ice core as a proxy of Antarctic temperature change versus SPECMAP age (Bender et al., 1994), with assignment of MIS and synchronous interstadial Dansgaard-Oeschger events $(\mathrm{D} / \mathrm{O})$ identified in the Greenland GISP2 ice core (Bender et al., 1999).

part of global conveyor circulation, responsible for interhemispheric heat transfer and ocean ventilation (Broecker and Denton, 1989; Rahmstorf, 1995; Berger and Wefer, 1996). From our interpretations and the present status of SPECMAP stratigraphy and ice-core correlations, we thus may state that global conveyor circulation responded to climate change on Milankovitch time scales and to some extent to short-term climate changes on millennial time scales. For interglacial periods, the operation of the modern warm-route conveyor mode is evident, implying a far southward injection of relatively warm and saline NADW into the ACC, compensated to a large extent by the northward outflow of warm surface and intermediate waters, which enter the South Atlantic via the Agulhas Current (Gordon et al., 1992). During glacial stages, the conveyor operates in cold route, which is characterised by prevailing cold southern-source water masses in the study area. 

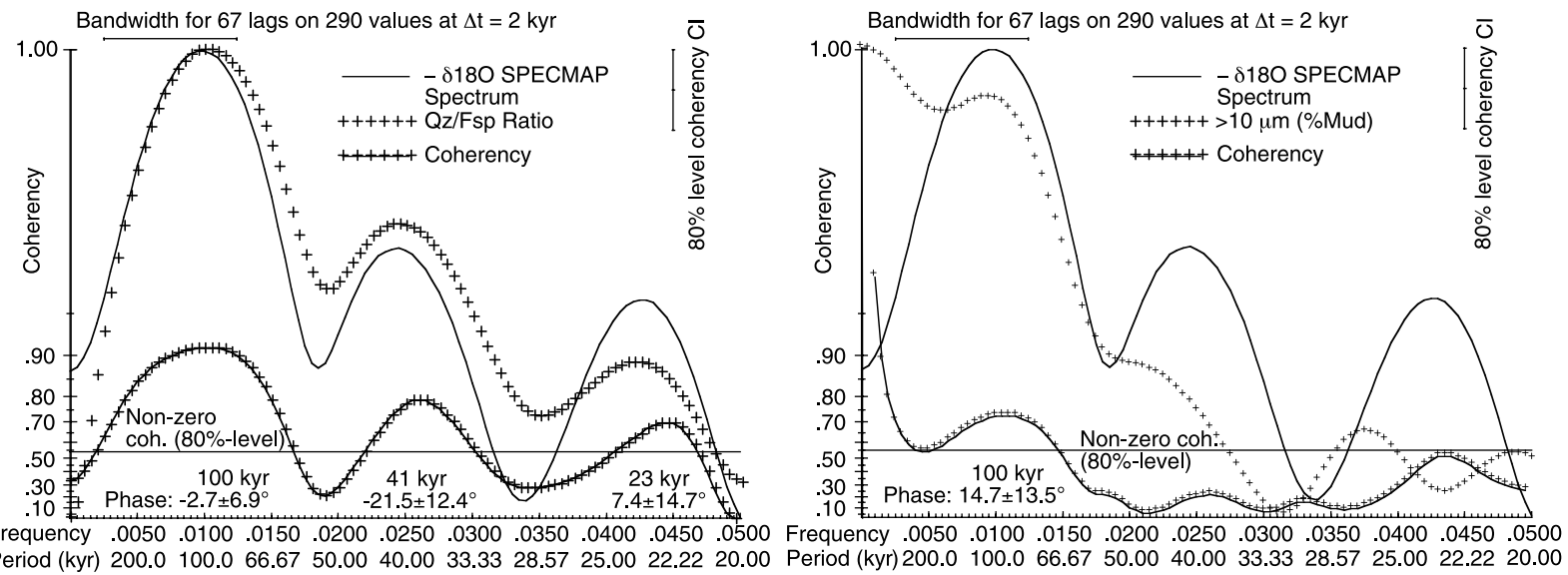

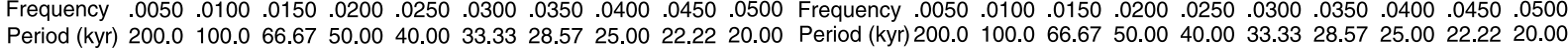

Fig. 12. Cross-spectral analysis between the $\delta^{18} \mathrm{O}$ SPECMAP stack (Imbrie et al., 1984) and Qz/Fsp ratios and percentage of sortable silt at Site 1089, with indications of phase spectra.

These results support palaeoceanographic reconstructions on the basis of other water-mass proxies. A diminished leakage of the Agulhas Current to the South Atlantic during glacial periods is recorded by changes in nannofossil assemblages in marine sediments off the South African cape region (Flores et al., 1999) and by strontium isotopes in detrital material in marine sediments of the southern Cape Basin (Goldstein et al., 1999). Benthic foraminiferal assemblages (Schmiedl and Mackensen, 1997) and benthic foraminiferal $\delta^{13} \mathrm{C}$ variations in South Atlantic sediment cores (Duplessy et al., 1988; Raymo et al., 1990; Mackensen and Bickert, 1999; Charles and Fairbanks, 1992) both suggest a weakened NADW influx to the south during glacial periods. Moreover, benthic foraminiferal $\delta^{13} \mathrm{C}$ records document a variable NADW influx on a millennial time scale, but on higher frequency as suggested by the clay-mineral proxy (Charles et al., 1996).

We are not able to deduce the triggers of variable conveyor circulation with confidence. While the formation of NADW is related to northern hemispheric insolation and ice-sheet dynamics (Broecker and Denton, 1989; Berger and Wefer, 1996), the intensities of the Agulhas Current and the ACC depend on temperatures and the configurations of the major wind fields in the southern hemisphere (Shannon et al., 1990; Klinck and Smith, 1993). Latest reconstructions from ice- core data and marine proxy records from the southern hemisphere indicate changes in atmospheric $\mathrm{CO}_{2}$ and variations in air and sea-surface temperatures to have preceded changes in global ice volume on short and long time scales (Charles et al., 1996; Little et al., 1997; Blunier et al., 1998; Brathauer and Abelmann, 1999; Vidal et al., 1999). This phase lead on the Milankovitch time scale is not evident from our data, which suggest a more or less synchronous response of regional conveyor circulation to global ice-volume changes, as also inferred from other sediment records in the southeastern South Atlantic by means of clay mineralogy (Diekmann et al., 1996, 1999). On the other hand, the inferred short-term fluctuations in conveyor circulation during MIS 3 correspond to air-temperature changes recorded in the Vostok ice core, when using a SPECMAP age model for both records. In turn, the comparison of benthic foraminiferal $\delta^{13} \mathrm{C}$ records and planktic foraminiferal $\delta^{18} \mathrm{O}$ records in sediment core RC11-83, recovered near Site 1089, revealed an anti-phase relationship between changes in NADW influx and sea-surface temperatures (Charles et al., 1996).

\subsection{Contour-current strengths in response to climate variability}

Grain-size variations of terrigenous mud, as potential indicators of variable contour-current 
strengths, show fluctuations consistent with glacial-interglacial alternations (Figs. 7 and 10). Silt/clay ratios of $0.45-0.95$ and values of 10 $20 \%$ for proportions of sortable silt demonstrate clear downcore changes. Maxima in both silt/clay ratios and percentages of sortable silt correspond to interglacial stages and the respective minima correspond to glacial stages. The coarsening of mud during interglacial stages might indicate a stronger current sorting of coarse silt and winnowing of fines by bottom currents, whereas the increase in fine material during glacial stages could be attributed to weaker bottom-current activity. Clues for this assumption also arise from $\mathrm{X}$-radiographs, which show faint stratification of calcareous oozes in interglacials whereas glacial intervals are dominated by pure bioturbation structures (Fig. 5). Moreover, abundant pyrite streaks in glacial intervals point to weaker bottom-water ventilation. This is consistent with glacial/interglacial variations in pyrite concentrations of the carbonate-free sediment fraction (Shipboard Scientific Party, 1999).

The interpretation of stronger interglacial bottom-current activities only holds true when the sediment sources remained constant through time. The constancy of Qz/Fsp ratios in the silt fraction (Figs. 7 and 10) indeed suggests more or less constant sources of silt-sized material. However, the sources of clay-sized material periodically changed, for reasons discussed in Section 4.3. The great differences between $M A R_{\text {Clay }}$ and $\mathrm{MAR}_{\text {Silt }}$ and between $\mathrm{MAR}_{\text {Kao }}$ and $\mathrm{MAR}_{\mathrm{Chl}}$ moreover reflect a stronger absolute input of clay-sized detritus from distant Antarctic and $\mathrm{Pa}-$ tagonian sources in relation to silt during glacial periods (Fig. 9). The observed grain-size signal in glacial intervals therefore could be explained by dilution through additional clay input, overprinting regional background sedimentation and the current-sorting effect.

In contrast to clay mineralogical parameters, time-series analysis of sortable silt only reveals strong spectral power in the $100-\mathrm{kyr}^{-1}$ frequency band of orbital eccentricity, coherent with global ice-volume changes at the same frequency (Fig. 12). Likewise, no evidence for significant shortterm changes in the abundance of sortable silt exists for the MIS 3 interval (Fig. 11). Variations in the percentages of sortable silt lag behind changes in global ice volume by $4.1 \pm 3.7 \mathrm{kyr}$, while the Qz/Fsp ratio of the clay fraction slightly leads global ice volume by $0.7 \pm 1.9 \mathrm{kyr}$ in the $100-\mathrm{kyr}^{-1}$ frequency band. Though the phase difference between both parameters and global ice volume approximately lies within the error range (Fig. 12), the significant differences in power spectra of both parameters suggest that the grain-size signal may be related to the variability in bottomcurrent sorting independently of changes in sediment sources.

Thus, high proportions of sortable silt indicate a stronger contour-current activity during interglacial rather than glacial periods. Since the bottom currents in the southern Cape Basin are linked to the outflow of deep Weddell Sea water masses from the Enderby Basin, which is situated in the northeastern part of the Weddell Gyre, this result is consistent with a higher production rate of dense bottom water in the southern Weddell Sea during times of highstands of sea level and the presence of floating ice shelves. Such boundary conditions are important to achieve supercooling of water masses beneath extensive ice shelves (Foldvik and Gammelsrød, 1988).

Grain-size characteristics in marine sediments of the Weddell Sea indeed demonstrate a weakening of bottom-water production during glacial periods in the Weddell Sea, because of grounded ice shelves that inhibit the supercooling mechanism (Fütterer et al., 1988; Pudsey, 1992; Weber et al., 1994; Gilbert et al., 1998). This glacial decline in bottom-water vigour apparently is also recorded in the deep drift sediments of the southern Cape Basin. Since the mostly carbonate-barren sediment sequences in the Weddell Sea do not provide a good age control on environmental change, the Site 1089 sediment record yields a better understanding of the timing of bottomwater formation. So it seems that episodes of strong bottom-water formation correspond to interglacial maxima with highest stands of sea level, recurring in a 100-kyr periodicity, and it seems that the variability in bottom-water formation is less sensitive to climatically induced changes in Antarctic ice dynamics and to sea-level fluctua- 
tions on shorter time scales. Moreover, the phase relationship between global ice volume and sea level and grain-size variability suggests a slightly delayed manifestation of strong bottom-water formation after sea-level rise and ice-shelf refloating during climate warming.

\section{Acknowledgements}

This study was funded by the Deutsche Forschungsgemeinschaft through Grants $\mathrm{Ku}$ 683/6 and Di-655/2. We thank the organisers of the Ocean Drilling Program for inviting us to participate in Leg 177 and we appreciate the kind assistance of the Joides Resolution ship crew and scientists. For sample preparation and technical support we are indebted to Rita Froehlking, Silvia Janisch, Claudia Leng, Norbert Lensch, Walter Luttmer, Maren Thomas, Jutta Vernaleken, Franziska Stenzel and numerous student trainees. Finally, we acknowledge the supportive reviews of Carol Pudsey and Dorrik Stow.

\section{References}

Behairy, A.K., Chester, R., Griffiths, A.J., Johnson, L.R., Stoner, J.H., 1975. The clay mineralogy of particulate material from some surface seawaters of the eastern Atlantic Ocean. Mar. Geol. 18, M45-M56.

Bender, M.L., Sowers, T., Dickson, M.L., Orchardo, J., Grootes, P., Mayewski, P.A., Meese, D.A., 1994. Climate correlations between Greenland and Antarctica during the past 100,000 years. Nature 372, 663-666.

Bender, M.L., Malaize, B., Orchardo, J., Sowers, T., Jouzel, J., 1999. High precision correlations of Greenland and Antarctic ice core records over the last $100 \mathrm{kyr}$. In: Clark, P.U., Webb, R.S., Keigwin, L.D. (Eds.), Mechanisms of Global Climate Change at Millennial Time Scales. Geophys. Monogr. 112, 149-164.

Berger, W.H., 1999. The 100-kyr ice-age cycle: internal oscillation or inclinational forcing? Int. J. Earth Sci. 88, 305-316.

Berger, W.H., Wefer, G., 1996. Expeditions into the past: paleoceanographic studies in the South Atlantic. In: Wefer, G., Berger, W.H., Siedler, G., Webb, D.J. (Eds.), The South Atlantic: Present and Past Circulation. Springer-Verlag, Berlin, pp. 363-410.

Biscaye, P.E., 1965. Mineralogy and sedimentation of recent deep-sea clay in the Atlantic Ocean and adjacent seas and oceans. Geol. Soc. Am. Bull. 76, 803-832.

Blunier, T., Chappellaz, J., Schwander, J., Dällenbach, A.,
Stauffer, B., Stocker, T.F., Raynaud, D., Jouzel, J., Clausen, H.B., Hammer, C.D., Johnsen, J., 1998. Asynchrony of Antarctic and Greenland climate change during the last glacial period. Nature 394, 739-743.

Bornhold, B.D., Summerhayes, C.P., 1977. Scour and deposition at the foot of the Walvis Ridge in the northernmost Cape Basin, South Atlantic. Deep-Sea Res. 24, 743-752.

Brathauer, U., Abelmann, A., 1999. Late Quaternary variations in sea-surface temperatures and their relationship to orbital forcing recorded in the Southern Ocean (Atlantic sector). Paleoceanography 14, 135-148.

Bremner, J.M., Willis, J.P., 1993. Mineralogy and geochemistry of the clay fraction of sediments from the Namibian continental margin and the adjacent hinterland. Mar. Geol. 115, 85-116.

Broecker, W., Denton, G.H., 1989. The role of ocean-atmosphere reorganizations in glacial cycles. Geochim. Cosmochim. Acta 53, 2465-2501.

Chamley, H., 1989. Clay Sedimentology. Springer-Verlag, Berlin.

Charles, C.D., Fairbanks, R.G., 1992. Evidence from Southern Ocean sediments for the effect of North Atlantic Deep Water flux on climate. Nature 355, 416-419.

Charles, C.D., Lynch-Stieglitz, J., Ninnemann, U.S., Fairbanks, R.G., 1996. Climate connections between the hemisphere revealed by deep sea sediment core/ice core correlations. Earth Planet. Sci. Lett. 142, 19-27.

Chester, R., Elderfield, H., Griffin, J.J., Johnson, L.R., Padgham, R.C., 1972. Eolian dust along the eastern margins of the Atlantic Ocean. Mar. Geol. 13, 91-105.

Cole, T.G., Shaw, H.F., 1983. The nature and origin of authigenic smectites in some Recent marine sediments. Clay Miner. $18,239-252$.

Cortese, G., Abelmann, A., 2002. Radiolarian-based paleotemperatures during the last $160 \mathrm{kyr}$ at ODP Site 1089 (Southern Ocean, Atlantic Sector). Palaeogeogr. Palaeoclimatol. Palaeoecol. S0031-0182(01)00499-0.

Diekmann, B., Petschick, R., Gingele, F.X., Fütterer, D.K., Abelmann, A., Brathauer, U., Gersonde, R., Mackensen, A., 1996. Clay mineral fluctuations in late Quaternary sediments of the southeastern South Atlantic: Implications for past changes of deep water advection. In: Wefer, G., Berger, W.H., Siedler, G., Webb, D.J. (Eds.), The South Atlantic: Present and Past Circulation. Springer-Verlag, Berlin, pp. 621-644.

Diekmann, B., Kuhn, G., Mackensen, A., Petschick, R., Fütterer, D.K., Gersonde, R., Rühlemann, C., Niebler, H.-S., 1999. Kaolinite and chlorite as tracers of modern and late Quaternary deep water circulation in the South Atlantic and the adjoining Southern Ocean. In: Fischer, G., Wefer, G. (Eds.), Use of Proxies in Paleoceanography: Examples from the South Atlantic. Springer-Verlag, Berlin, pp. 285 313.

Diekmann, B., Kuhn, G., Rachold, V., Abelmann, A., Brathauer, U., Fütterer, D.K., Gersonde, G., Grobe, H., 2000. Terrigenous sediment supply in the Scotia Sea (Southern Ocean): Response to Late Quaternary ice dynamics in Pa- 
tagonia and on the Antarctic Peninsula. Palaeogeogr. Palaeoclimatol. Palaeoecol. 162, 357-387.

Duplessy, J.C., Shackleton, N.J., Fairbanks, R.G., Labeyrie, L.D., Oppo, D., Kallel, N., 1988. Deep water source variations during the last climatic cycle and their impact on global deep water circulation. Paleoceanography 3, 343-360.

Ehrmann, W.U., Melles, M., Kuhn, G., Grobe, H., 1992. Significance of clay mineral assemblages in the Antarctic Ocean. Mar. Geol. 107, 249-273.

Eisma, D., Kalf, J., van der Gaast, S.J., 1978. Suspended matter in the Zaire estuary and the adjacent Atlantic Ocean. Neth. J. Sea Res. 12, 382-406.

Flores, J.A., Gersonde, R., Sierro, F.J., 1999. Pleistocene fluctuations in the Agulhas Current Retroflection based on the calcareous plankton record. Mar. Micropaleontol. 37, 1-22.

Foldvik, A., Gammelsrød, T., 1988. Notes on Southern Ocean hydrography, sea-ice and bottom water formation. Palaeogeogr. Palaeoclimatol. Palaeoecol. 67, 3-17.

Froelich, P.N., Malone, P.N., Hodell, D.A., Ciesielski, P.F., Warnke, D.A., Westall, F., Hailwood, E.A., Nobes, D.C., Fenner, J.M., Mienert, J., Mwenifumbo, C.J., Mueller, D.W., 1991. Biogenic opal and carbonate accumulation rates in the sub-Antarctic South Atlantic: the late Neogene of Meteor Rise Site 704. In: Ciesielski, P.F., Kristoffersen, Y. et al. (Eds.), Proc. ODP Sci. Results, vol. 114, 515-550.

Fütterer, D.K., Grobe, H., Grünig, S., 1988. Quaternary sediment patterns in the Weddell Sea: relations and environmental conditions. Paleoceanography 3, 551-561.

Gersonde, R., Hodell, D.A., Blum, P. et al., 1999. Proc. ODP Init. Reports 177 [CD-ROM].

Gilbert, I.M., Pudsey, C.J., Murray, J.W., 1998. A sediment record of cyclic bottom-current variability from the northwest Weddell Sea. Sediment. Geol. 115, 185-214.

Gingele, F.X., 1996. Holocene climatic optimum in Southwest Africa - evidence from the marine clay mineral record. Palaeogeogr. Palaeoclimatol. Palaeoecol. 122, 77-87.

Goldstein, S.L., Hemming, S.R., Kish, S., Rutberg, R., 1999. Strontium isotopes in South Atlantic detritus: A surface current proxy and tracer of Agulhas leakage. Ninth Annual Goldschmidt Conference, Lunar Planet. Inst., Houston, TX, p. 7537 [CD-ROM].

Gorbunova, Z.N., 1976. Clay-sized minerals from cores of the southeast Pacific Ocean. In: Hollister, C.D., Craddock, C. et al. (Eds.), Init. Rep. DSDP 35, 479-488.

Gordon, A.L., Weiss, R.F., Smethie, W.M.J., Warner, M.J., 1992. Thermocline and intermediate water communication between the South Atlantic and Indian Oceans. J. Geophys. Res. 97 (C5), 7223-7240.

Hodell, D.A., Charles, C.D., Sierro, F.J., 2001. Late Pleistocene evolution of the ocean's carbonate system. Earth Planet. Sci. Lett. 192, 109-124.

Honnorez, J., 1981. The aging of the oceanic crust at low temperature. In: Emiliani, C. (Ed.), The Oceanic Lithosphere. The Sea, Vol. 7. John Wiley and Sons, New York, pp. $525-587$.

Imbrie, J., Hays, J.D., Martinson, D.G., McIntyre, A., Mix, A.C., Morley, J.J., Pisias, N.G., Prell, W.L., Shackleton,
N.J., 1984. The orbital theory of Pleistocene climate: Support from a revised chronology of the marine $\delta^{18} \mathrm{O}$ record. In: Berger, A., Imbrie, J., Hays, J., Kukla, G., Saltzman, B. (Eds.), Milankovitch and Climate. NATO ASI SERIES. D. Reidel, Dordrecht, pp. 269-305.

Imbrie, J., McIntyre, A., Mix, A., 1989. Oceanic response to orbital forcing in the late Quaternary: observational and experimental strategies. In: Berger, A., Schneider, S., Duplessy, J.C. (Eds.), Climate and Geo Sciences, A Challenge for Science and Society in the 21st Century. Kluwer, Dordrecht, pp. 121-164.

Jokat, W., Oerter, H., 1998. Die Expedition ANTARKTISXIV mit FS 'Polarstern': Bericht vom Fahrtabschnitt ANT-XIV/3. Berichte zur Polarforschung, 267. Alfred-Wegener-Institut für Polar- und Meeresforschung, Bremerhaven.

Kanfoush, S.L., Hodell, D.A., Charles, C.D., Guilderson, T.P., Mortyn, P.G., Ninnemann, U.S., 2000. Millennialscale instability of the Antarctic ice sheet during the last glaciation. Science 288, 1815-1818.

Keir, R.S., 1988. On the late Pleistocene ocean geochemistry and circulation. Paleoceanography 3, 413-445.

Klinck, J.M., Smith, D.A., 1993. Effect of wind changes during the last glacial maximum on the circulation in the Southern Ocean. Paleoceanography 8, 427-433.

Knies, J., Vogt, C., Stein, R., 1999. Late Quaternary growth and decay of the Svalbard/Barents Sea ice sheet and paleoceanographic evolution in the adjacent Arctic Ocean. Geo-Mar. Lett. 18, 195-202.

Kolla, V., Henderson, L., Biscaye, P., 1976. Clay mineralogy and sedimentation in the western Indian Ocean. Deep-Sea Res. 23, 949-961.

Little, M.G., Schneider, R., Kroon, D., Price, B., Summerhayes, C.P., Segel, M., 1997. Trade wind forcing of upwelling, seasonality, and Heinrich events as a response to subMilankovitch climate variability. Paleoceanography 12,568 576.

Lutjeharms, J.R.E., 1996. The exchange of water between the South Indian and South Atlantic Oceans. In: Wefer, G., Berger, W.H., Siedler, G., Webb, D.J. (Eds.), The South Atlantic: Present and Past Circulation. Springer-Verlag, Berlin, pp. 125-162.

Mackensen, A., Bickert, T., 1999. Stable carbon isotopes in benthic foraminfera. In: Fischer, G., Wefer, G. (Eds.), Use of Proxies in Paleoceanography: Examples from the South Atlantic. Springer-Verlag, Berlin, pp. 229-254.

Martinson, D.G., Pisias, N.G., Hays, J.D., Imbrie, J., Moore, T.C., Shackleton, N.J., 1987. Age dating and the orbital theory of the ice ages: Development of a high-resolution 0 to 300,000-year chronostratigraphy. Quat. Res. 27, 1-29.

McCave, I.N., Manighetti, B., Robinson, S.G., 1995. Sortable silt and fine sediment size/composition slicing: Parameters for palaeocurrent speed and palaeoceanography. Paleoceanography 10, 593-610.

Müller, P.J., Schneider, R., 1993. An automated leaching method for the determination of opal in sediments and particulate matter. Deep-Sea Res. I 40, 425-444. 
Orsi, A.H., Whitworth, T., III, Nowlin, W.D., Jr., 1995. On the meridional extent and fronts of the Antarctic Circumpolar Current. Deep-Sea Res. I 42, 641-673.

Paillard, D., Labeyrie, L., Yiou, P., 1996. Macintosh program performs time-series analysis. EOS Trans. AGU 77, 379.

Pastouret, L., Chamley, H., Delibrias, G., Duplessy, J.-C., Thiede, J., 1978. Late Quaternary climate changes in western tropical Africa deduced from deep-sea sedimentation off the Niger delta. Oceanol. Acta 1, 217-232.

Peterson, R.G., Stramma, L., 1991. Upper-level circulation in the South Atlantic Ocean. Progr. Oceanogr. 26, 1-73.

Petschick, R., Kuhn, G., Gingele, F.X., 1996. Clay mineral distribution in surface sediments of the South Atlantic: sources, transport, and relation to oceanography. Mar. Geol. 130, 203-229.

Pudsey, C.J., 1992. Late Quaternary changes in Antarctic Bottom Water velocity inferred from sediment grain size in the northern Weddell Sea. Mar. Geol. 107, 9-33.

Rahmstorf, S., 1995. Bifurcations of the Atlantic thermohaline circulation in response to changes in the hydrological cycle. Nature 378, 145-149.

Raymo, M.E., Ruddiman, W.F., Shackleton, N.J., Oppo, D.W., 1990. Evolution of Atlantic-Pacific $\delta^{13} \mathrm{C}$ gradients over the last 2.5 m.y. Earth Planet. Sci. Lett. 97, 353368.

Reid, J.L., 1989. On the total geostrophic circulation of the South Atlantic Ocean: Flow patterns, tracers, and transports. Progr. Oceanogr. 23, 149-244.

Robert, C., Maillot, H., 1983. Palaeoenvironmental significance of clay mineralogical and geochemical data, southwest Atlantic, Deep Sea Drilling Project Legs 36 and 71. In: Ludwig, W.J., Krashenikov, V.A. et al. (Eds.), Init. Reports DSDP 71, 317-343.

Schmiedl, G., Mackensen, A., 1997. Late Quaternary paleoproductivity and deep water circulation in the eastern South
Atlantic Ocean: Evidence from benthic foraminifera. Palaeogeogr. Palaeoclimatol. Palaeoecol. 130, 43-80.

Shannon, L.V., Agenbag, J.J., Walker, N.D., Lutjeharms, J.R.E., 1990. A major perturbation in the Agulhas retroflection area in 1986. Deep-Sea Res. 37, 493-512.

Shipboard Scientific Party, 1999. Site 1089. In: Gersonde, R., Hodell, D.A., Blum, P. et al. (Eds.), Proc. ODP Init. Reports 177, 1-97 [CD-ROM].

Stein, R., 1985. Rapid grain-size analyses of clay and silt fraction by SediGraph 5000D: Comparison with Coulter counter and Atterberg methods. J. Sediment. Petrol. 55, 590-593.

Tucholke, B.E., Embley, R.W., 1984. Cenozoic regional erosion of the abyssal sea floor off South Africa. In: Schlee, J.S. (Ed.), Interregional Unconformities and Hydrocarbon Accumulation. AAPG Memoir 36. American Association of Petroleum Geologists, Tulsa, OK, pp. 145-164.

Usbeck, R., 1999. Modeling of marine biogeochemical cycles with an emphasis on vertical particle fluxes. Berichte zur Polarforschung, 332. Alfred-Wegener-Institut für Polarund Meeresforschung, Bremerhaven.

Van der Merve, C.R., 1966. Soil groups and subgroups of southern Africa. Publ. Dep. Agric. Tech. Serv. S. Afr. 231, $1-353$.

Vidal, L., Schneider, R.R., Marchal, O., Bickert, T., Stocker, T.F., Wefer, G., 1999. Link between the North and South Atlantic during the Heinrich events of the last glacial period. Clim. Dyn. 15, 909-919.

Walter, H.J., Hegner, E., Diekmann, B., Kuhn, G., Rutgers van der Loeff, M.M., 2000. Provenance and transport of terrigenous sediment in the South Atlantic Ocean and their relations to glacial and interglacial cycles: $\mathrm{Nd}$ and $\mathrm{Sr}$ isotope evidence. Geochim. Cosmochim. Acta 64, 3813-3827.

Weber, M.E., Bonani, G., Fütterer, D.K., 1994. Sedimentation processes within channel-ridge systems, southeastern Weddell Sea, Antarctica. Paleoceanography 9, 1027-1048. 